\title{
Review of Crocodile (Reptilia: Crocodilia) and Dugong (Mammalia: Sirenia) Sightings in the Federated States of Micronesia ${ }^{1}$
}

\author{
Donald W. Buden ${ }^{2,3}$ and Fohn Haglelgam ${ }^{4}$
}

\begin{abstract}
Three confirmed occurrences of crocodiles, one identified as Crocodylus porosus (two others presumed C. porosus), and four occurrences of the dugong, Dugong dugon, are recorded for the Federated States of Micronesia. The records of a crocodile and a dugong on Eauripik Atoll and a dugong on Kosrae are reported in the literature for the first time. On geographic grounds, the crocodiles and dugongs recorded from Yap State, in the western part of the FSM, probably pertain to vagrants from Palau, approximately $450 \mathrm{~km}$ to the southwest, whereas those recorded from the eastern islands (Pohnpei and Kosrae) are more likely to have originated from populations in the Bismarck Archipelago and Solomon Islands area, approximately $1,500 \mathrm{~km}$ to the southwest, rather than from Palau, which is a much greater distance to the west.
\end{abstract}

The island Nation of the Federated States of Micronesia (FSM) includes over 600 islands distributed among Yap, Chuuk, Pohnpei, and Kosrae States and spans across approximately 2,700 $\mathrm{km}$ of the west-central Pacific Ocean, between the Republic of Palau to the west and the Marshall Islands to the east (Figure 1). The islands of the FSM and the Republic of Palau together make up the Caroline Islands. There are no known breeding populations of crocodiles or dugongs in the FSM; the nearest ones are those of the saltwater crocodile, Crocodylus porosus (Schneider), and the dugong, Dugong dugon (Müller), in Palau, approximately $400 \mathrm{~km}$ west of Yap proper, and in the Bismarck Archipelago, ca. $1,500 \mathrm{~km}$ south-southwest of Pohnpei and Kosrae (Britton 1995, Marsh et al. 2002). Some of the crocodile sightings in

\footnotetext{
${ }^{1}$ Manuscript accepted 2 February 2010. .fm).

2 Corresponding author (e-mail: don_buden@comfsm

${ }^{3}$ Division of Natural Sciences and Mathematics, College of Micronesia-FSM, P.O. Box 159, Kolonia, Pohnpei, Federated States of Micronesia 96941.

${ }^{4}$ Division of Social Sciences, College of MicronesiaFSM, P.O. Box 159, Kolonia, Pohnpei, Federated States of Micronesia 96941 (e-mail: johnh@comfsm.fm).
}

Pacific Science (2010), vol. 64, no. 4:577-583

doi: $10.2984 / 64.4 .577$

(C) 2010 by University of Hawai'i Press

All rights reserved the FSM can be discounted as unsubstantiated rumor, including, most recently, a spate of purported sightings during August 2009 possibly based on a story made up by local fishermen to keep fishing waters for themselves (Anonymous 2009). A few years earlier, rumors of a crocodile in another part of Pohnpei also flourished for several weeks before subsiding, and efforts by D.W.B. and Brian Lynch (Marine Sciences instructor, College of Micronesia) to verify the sightings were unsuccessful. Three confirmed sightings of crocodiles in the FSM are reported in this study. One is well documented in the literature, another has been previously published but remains poorly known, and another is reported here for the first time. Dugongs have been recorded only twice previously in the FSM, both times in Yap. We report on two additional records, one from Eauripik Atoll and another from Kosrae, doubling the number of recorded sightings.

\section{MATERIALS AND METHODS}

Details of records of crocodiles and dugongs in the FSM were obtained from archival documents, scientific literature, and correspondence with individuals with first-hand knowledge of the sightings on their home islands. The records of a crocodile and dugong on Eauripik Atoll reported here for the first time are based on observations by J.H. 


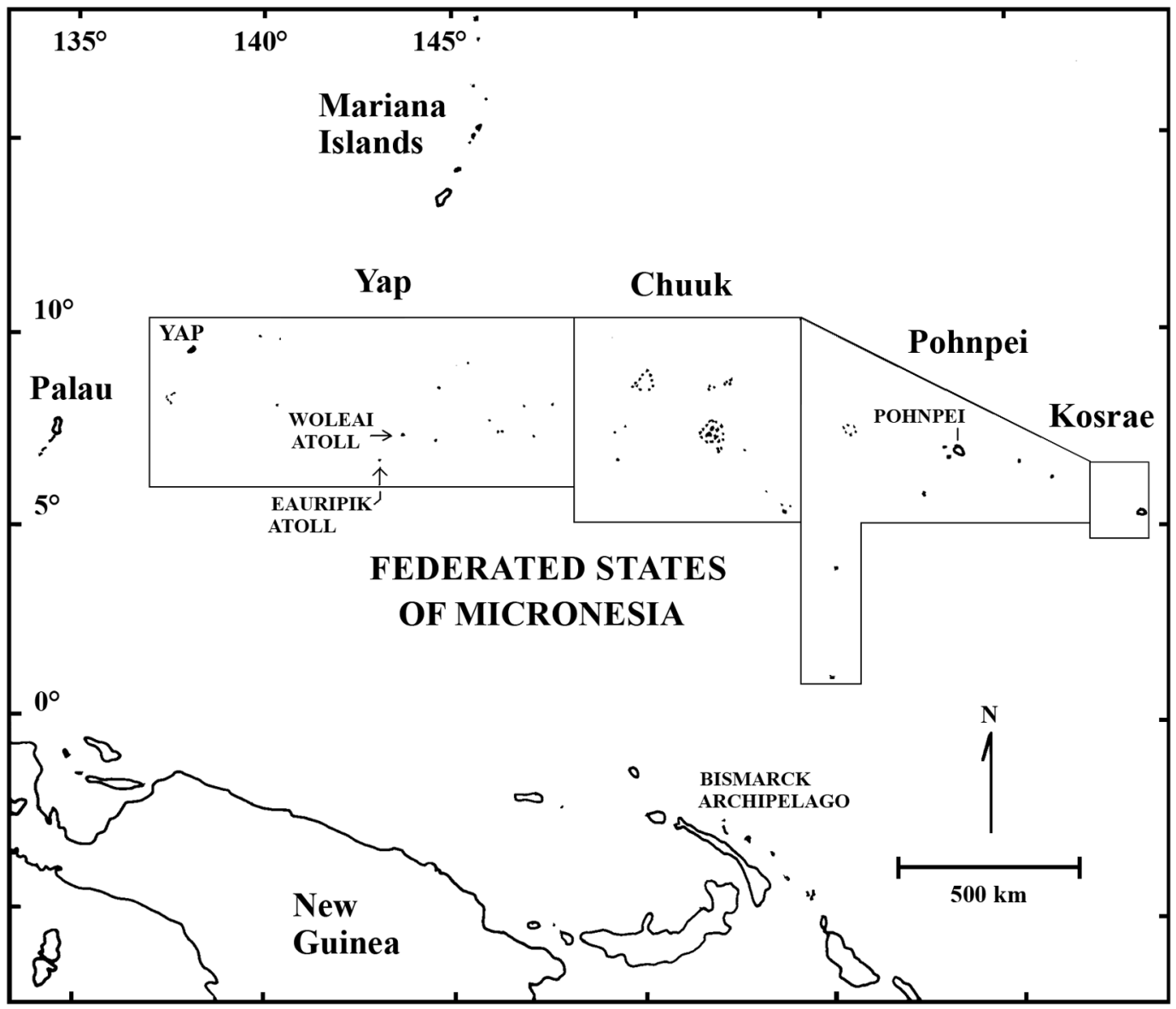

Figure 1. Location of the Federated States of Micronesia and islands where crocodiles and dugongs have been recorded.

\section{OBSERVATIONS AND RESULTS}

\section{Crocodiles}

The most thoroughly documented and frequently cited record of a crocodile in the FSM is a large $C$. porosus captured in mangroves in southern Pohnpei in 1971 (Figure $2)$. It was initially reported in an article in Highlights, a Pacific Trust Territory newsletter (Manke 1971), and later in the journal $\mathrm{Co}^{-}$ peia (Allen 1974), and still later reprised in a local Pohnpei newspaper (Island Tribune) in a column devoted to historical anecdotes (Peterson 1998). The Tribune reported the animal as being 14 feet $[4.3 \mathrm{~m}]$ long, the
Highlights article indicated it in two places as being 12 feet $[3.7 \mathrm{~m}$ ] long (probably rounding off) and as 12 feet, 6 inches [3.8 m] where more specific measurements were given; the latter measurement agrees with the Copeia account, where it was reported as being $380 \mathrm{~cm}$ in total length. The Copeia account stated that the animal was captured on 28 March 1971, after three domestic pigs mysteriously disappeared over a 6-month period. This date is likely off by a month, possibly as a misinterpretation of the Highlights account, which stated that the first pig (weighing 200 pounds [90.7 kg]) disappeared in September 1970, the second on 12 March 1971, and the third on 

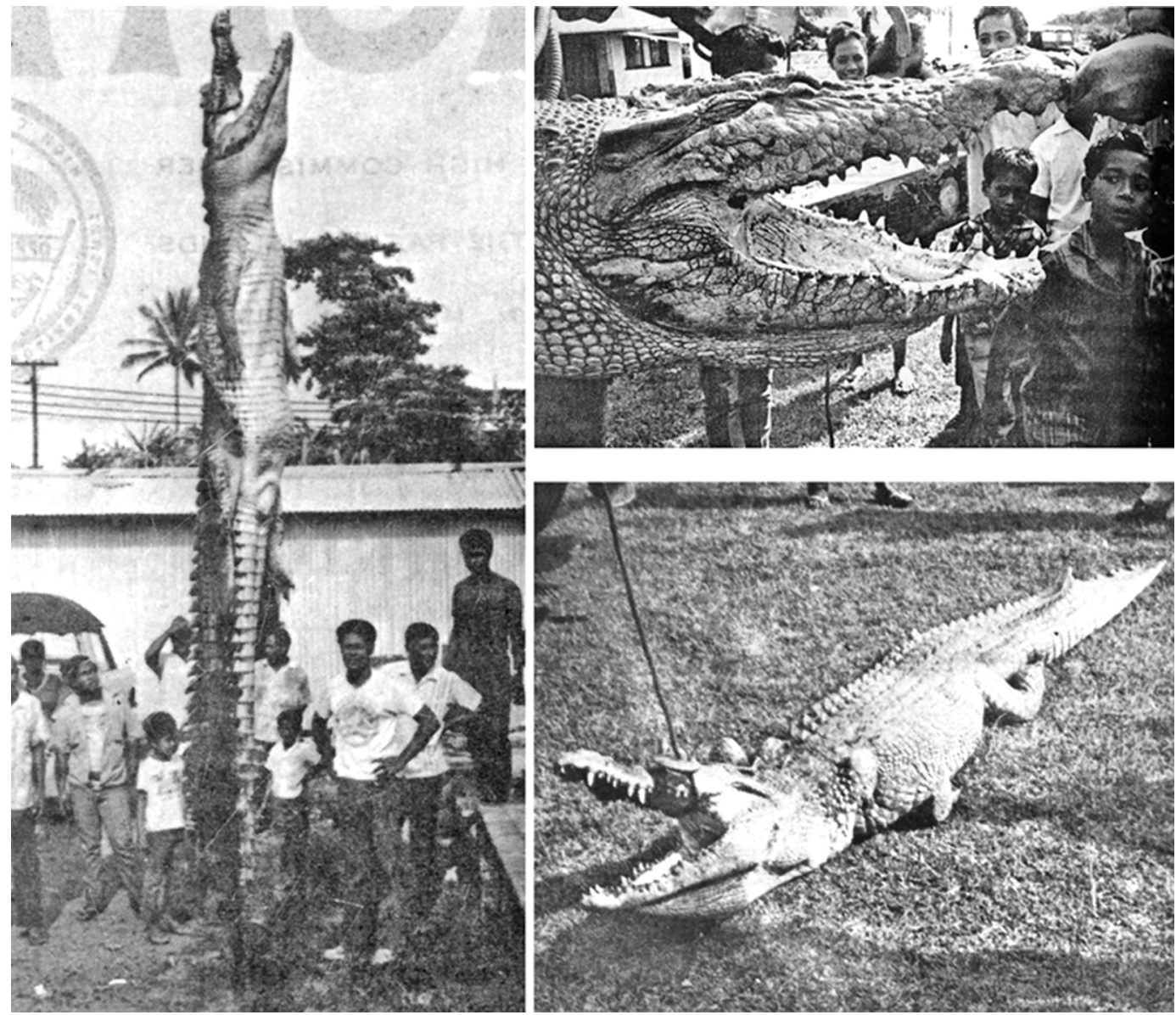

Figure 2. Crocodile captured on Pohnpei in 1971; photographs courtesy of Carol Varas and Micronesian Seminar photo archives, Kolonia, Pohnpei.

26 March. The article further stated that after the loss of the third pig, a large wooden trap (30 feet $[9.1 \mathrm{~m}]$ long, 8 feet $[2.4 \mathrm{~m}]$ wide, 7 feet $[2.1 \mathrm{~m}]$ high) was set in the mangroves and baited with a live pig, and that after being sprung several times by dogs and other pigs, the crocodile was trapped and killed "early last Sunday morning." Inasmuch as that issue of the newsletter was dated 1 May 1971, and the preceding issue was 15 April, the capture likely took place on 25 April and not on 28 March (miswritten 21 March in Buden [2008]), as was indicated in Copeia. No specific date of capture was reported in the Tribune account.
Another crocodile, presumably also $C$. porosus, was recorded on Woleai Atoll, Yap State, during late March/early April 1986 (Eldredge 1994) but has not been widely cited. The Eldredge report, based on information furnished by Andrew Smith, who worked for Yap Marine Resources at the time, indicated that tracks $2-3$ feet [0.6-0.9 $\mathrm{m}$ ] apart, and with a slide mark in the middle, were observed leading from the lagoon to a brackish swamp on Paliyaw Island. Woleai residents postulated that the animal arrived from Palau on a large log (30-40 feet [9.1$12.2 \mathrm{~m}]$ long and 4 feet $[1.2 \mathrm{~m}]$ in diameter) seen floating in the lagoon. Smith (pers. 
comm., e-mail 8 September 2009) stated that his wife (Roberta Legasuguw Smith), a former resident of Woleai, was later able to confirm that the tracks she saw on Woleai were those of a medium-sized crocodile based on her subsequent observation of tracks in Palau and later in Australia, where the Smiths now reside. Smith (pers. comm.) indicated that the tracks were first found by Tino Uolai, but he (Smith) did not know of any confirmed sightings of the animal, only unconfirmed reports of fishermen seeing it floating in the lagoon at night. However, Stanley Retogral, a supervisor for Yap Woleai Atoll schools and former resident of Woleai, recalled (pers. comm., e-mail 24 September 2009) that the tracks were first seen on Paliyaw and then on nearby Raur Island, that the animal was observed by resident islanders, and that it was last seen in a depression or crack in the reef, but when the islanders left and returned to the site with spears, it had disappeared and was not seen again.

The only other confirmed record known to us of a crocodile in the FSM is of a Crocodylus cf. porosus $1.0-1.5 \mathrm{~m}$ long observed by J.H. as a young boy on Eauripik Island, Eauripik Atoll, Yap State, ca. 1959. The crocodile was first seen by resident islanders at it was running across the beach to enter the water on the ocean side of the island. It was subsequently caught in a fish net, killed with a spear, and brought ashore, where it was seen by many islanders before being buried. The record from Eauripik, although known to many Yapese, has not been previously reported in the literature.

\section{Dugongs}

The dugong, Dugong dugon, ranges widely from the east coast of Africa to southern Asia and the Indo-Australian archipelago to the islands of the western and southern $\mathrm{Pa}$ cific Ocean. There are two recorded occurrences in the FSM, both in Yap, probably vagrants from a small breeding population in Palau: one caught and sold at market in 1963, and another seen by a turtle hunter in 1977 (Nishiwaki et al. 1979, Eldredge 1991). No other locality records were noted in the most recently updated checklist of birds and mammals of Micronesia (Wiles 2005), although Eldredge (1991) reported on several sightings of dugongs in southern Guam in 1975 and 1984.

We are aware of two additional confirmed occurrences of dugongs in the FSM previously unreported in the scientific literature. J.H. observed a dugong in the lagoon at Eauripik Atoll during the summer of 1962. It was observed frequently by many islanders in an area of extensive sea-grass beds and eluded numerous attempts at capture over a period of at least 2 months before it disappeared.

In addition, on 21 July 2006, a female dugong measuring $2.5 \mathrm{~m}$ long and weighing an estimated 500 pounds [227 kg] (measurements by Kosrae marine resources staff [ $\mathrm{Ka}$ trina Adams, pers. comm.]) was found dead on the beach at Kosrae Village Ecolodge, Kosrae Island (Figure 3). The size of the animal indicates that it almost certainly was an adult female (H. Marsh, pers. comm.), whereas most other extralimital records of dugongs have been males (Marsh et al. 1984). It was apparently only recently dead because blood was still draining from one ear when it was found, and there was no degradation by scavengers or evidence of myiasis. The cause of death is uncertain. There was a recent abrasion on the head, but aside from some apparently old scarring on the body, no other signs of injury or illness. Observers at the scene speculated that the animal may have been hurt in the abnormally high surf the previous night. A tissue sample was collected for DNA analysis but was lost before it could be studied; nothing of the carcass was saved. Although a brief report of this find with an accompanying photo occurs on the Kosrae Village Web site at http://www.kosraevillage .com/discovery.shtml, the record has not been previously reported in the scientific literature.

\section{DISCUSSION}

Although far from potential source populations in Palau and Melanesia, the occasional appearance of crocodiles and dugongs in 

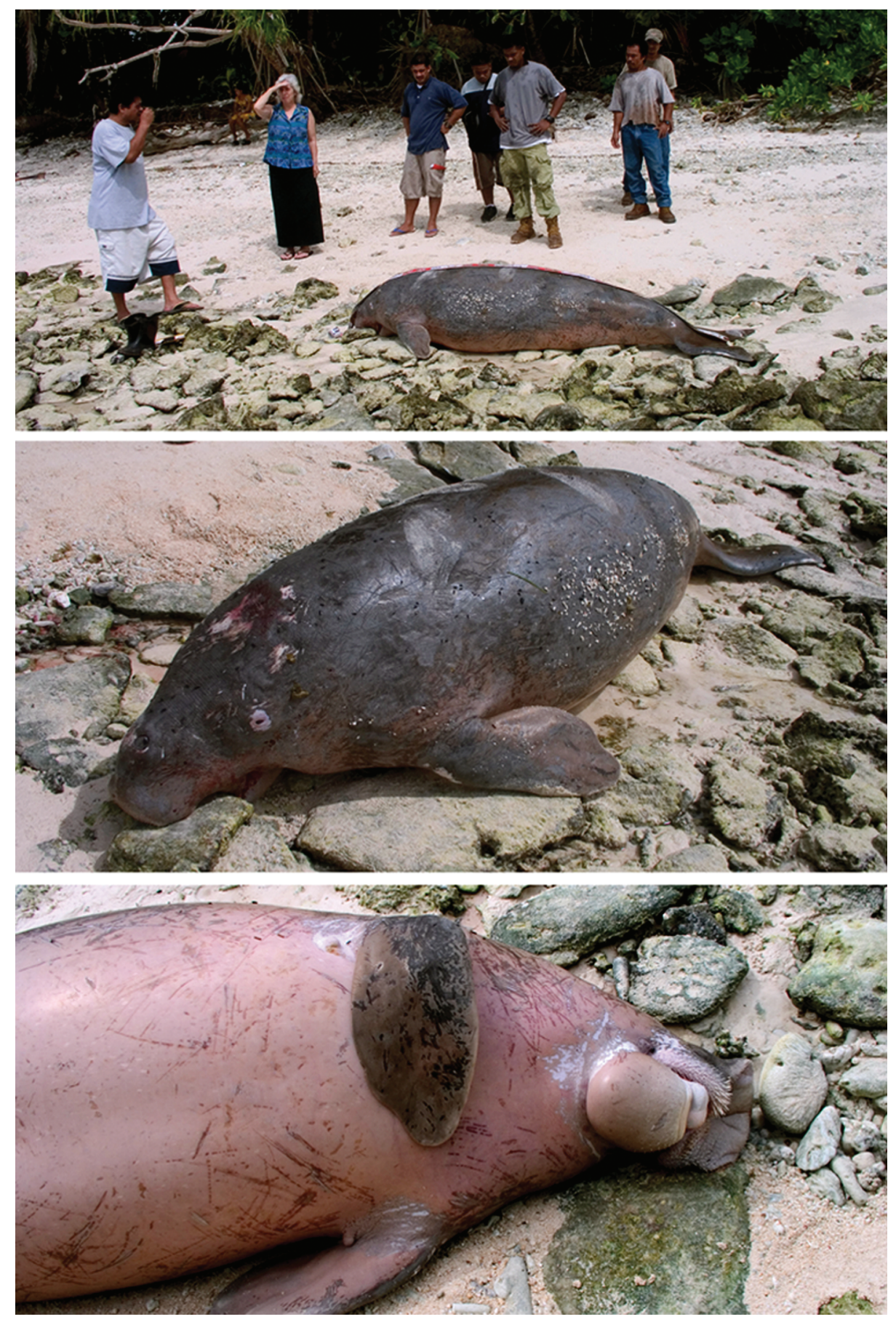

Figure 3. Dugong found dead on Kosrae in 2006; photographs courtesy of Katrina Adams and Kosrae Village Ecolodge. 
the FSM is not completely unexpected. As its name implies, the saltwater crocodile is highly tolerant of salt water and has been observed from ships at sea far from land (Ditmars 1967). Extralimital records of the saltwater crocodile have been documented elsewhere in the central and South Pacific in the Marshall Islands (Manolis 2005; N. Vander Velde, pers. comm.), Nauru (Webb 1994, Buden 2008), and Fiji and New Caledonia (Eldredge 1994). Many of the high islands of the FSM appear to offer suitable habitat for a resident population of this species given their extensive areas of mangrove into which drain numerous freshwater rivers and streams. However, crocodiles going out to sea far from their island of origin typically are lone, subordinate males looking for a new home and thus unlikely to initiate a new population (Britton 1995 and pers. comm.).

Studies in Australia indicate that dugongs frequently undertake large-scale coastal movements of over $100 \mathrm{~km}$ and up to $\sim 600$ $\mathrm{km}$ (Sheppard et al. 2006). Dugongs are also capable of crossing ocean trenches. For example, the lone male that arrived in Cocos (Keeling) Islands in June 2002 must have traveled over $1,000 \mathrm{~km}$ (the distance to the nearest population in Indonesia) (Hobbs et al. 2007). He was still present as of May 2009 (ABC News 2009).

\section{ACKNOWLEDGMENTS}

We thank Katrina Adams and Kosrae Village Ecolodge for providing images of the dugong found at Kosrae, Carol Varas and Micronesian Seminar for images of the crocodile captured on Pohnpei, and Shaun Suliol, IT Office, College of Micronesia, for preparing composite illustrations of these animals. We also thank Stanley Retogral, Andrew Smith, and Roberta Legasuguw Smith for sharing their recollections of the crocodile on Woleai Atoll, and Helene Marsh for reviewing an early draft of the manuscript.

\section{Literature Cited}

ABC News [Australian Broadcasting Corporation]. 2009. Love in the air for lonely dugong. [updated 29 May 2009]. Available at http://www.abc.net.au/news/stories/ 2009/05/28/2583714.htm

Allen, G. R. 1974. The marine crocodile, Crocodylus porosus, from Pohnpei, eastern Caroline Islands, with notes on food habits of crocodiles from the Palau Archipelago. Copeia 1974:553.

Anonymous. 2009. Crocodile rock! Kaselehlie Press [25 November 2009] 9 (26): 1.

Britton, A. 1995 [updated 2009]. Crocodylus porosus (Schneider, 1801). Available at http://www.flmnh.ufl.edu/cnhc/csp_cpor .htm

Buden, D. W. 2008. The reptiles of Nauru. Pac. Sci. 62:499-507.

Ditmars, R. L. 1967. Reptiles of the world. New rev. ed. Macmillan Co., New York.

Eldredge, L. G. 1991. Annotated checklist of the marine mammals of Micronesia. Micronesica 24:217-230.

-1994. Perspectives in aquatic exotic species management in the Pacific islands. Vol. 1. Introductions of commercially significant aquatic organisms to the Pacific Islands. South Pacific Commission, New Caledonia.

Hobbs, J.-P. A., A. J. Frisch, J. Hender, and J. J. Gilligan. 2007. Long-distance oceanic movement of a solitary dugong (Dugong dugon) to the Cocos (Keeling) Islands. Aquat. Mamm. 33:175-178.

Manke, J., ed. 1971. "First ever" crocodile for Ponape. Highlights. 1 May 1971:1-2 [newsletter, Office of the High Commissioner, Trust Territory of the Pacific Islands, Saipan, Mariana Islands].

Manolis, C. 2005. Long-distance movement by a saltwater crocodile. Crocodile Specialist Group Newsl. 24 (4): 18.

Marsh, H., G. E. Heinsohn, and L. M. Marsh. 1984. Breeding cycle, life history and population dynamics of the dugong, Dugong dugon Sirenia: Dugongidae. Aust. J. Zool. 32:767-785.

Marsh, H., H. Penrose, C. Eros, and J. Hugues. 2002. Dugong: Status reports and action plans for countries and territories. United Nations Environment Program. Early Warning and Assessment Report Series 1. Available at http:// www.tesag.jcu.edu.au/dugong

Nishiwaki, M., T. Kasuya, N. Miyazaki, T. 
Tobayama, and T. Kataoka. 1979. Present distribution of the dugong in the world. Sci. Rep. Whales Res. Inst. Tokyo 31:133-141.

Peterson, L. 1998. Bits o' history? Island Tribune [Kolonia, Pohnpei], 15-28 October 1998.

Sheppard, J., A. Preen, H. Marsh, I. Lawler, S. Whiting, and R. Jones. 2006. Movement heterogeneity of dugongs, Dugong dugon (Müller) over large spatial scales. J. Exp. Mar. Biol. Ecol. 334:64-83.

Webb, G. 1994. Nauru: Vagrant crocodile. Crocodile Specialist Group Newsl. 13 (4): 13.

Wiles, G. J. 2005. A checklist of the birds and mammals of Micronesia. Micronesica 38:141-189.

Addendum: As this article went to press, the authors received an e-mail from James Stanford (Brown Tree Snake Project, Rapid Response Team Coordinator/Biologist, Guam National Wildlife Refuge) regarding the possible sighting of a crocodile at Ngulu Atoll, Yap. According to an SSB radio transmission by Captain Dominick Tafleicheng on the MV Hapilmobol anchored off Ngulu Island on 8 June 2010, resident islanders observed a crocodile about $1.0-1.5 \mathrm{~m}$ long on the shore of one of the small uninhabited islands just north of the main island on 7 June 2010. The animal escaped into the ocean when sighted. The islanders continued to search for the animal throughout the afternoon but it was not seen again. Inasmuch as Ngulu Atoll is the part of the FSM that is nearest to a breeding population of $C$. porosus on Palau, the occurrence of a vagrant crocodile at Ngulu is not unlikely. However, because substantive corroborative evidence is lacking and details of the sighting remain vague, we consider the record as unconfirmed. 
